\title{
Building Britannia: pre-Flavian private and public construction across Southern Britain
}

Article

Accepted Version

Fulford, M. and Machin, S. (2021) Building Britannia: preFlavian private and public construction across Southern Britain. Britannia, 52. ISSN 1753-5352 doi:

https://doi.org/10.1017/S0068113X2100009X Available at https://centaur.reading.ac.uk/100234/

It is advisable to refer to the publisher's version if you intend to cite from the work. See Guidance on citing.

To link to this article DOI: http://dx.doi.org/10.1017/S0068113X2100009X

Publisher: Cambridge University Press

All outputs in CentAUR are protected by Intellectual Property Rights law, including copyright law. Copyright and IPR is retained by the creators or other copyright holders. Terms and conditions for use of this material are defined in the End User Agreement.

www.reading.ac.uk/centaur

\section{CentAUR}


Central Archive at the University of Reading

Reading's research outputs online 
Building Britannia: Pre-Flavian Private and Public Construction across Southern Britain

By

Michael Fulford and Sara Machin

Abstract

Excavation of the Roman tilery at Little London, Pamber, Hampshire has prompted a re-assessment of the dating of relief-patterned tile, assigning the bulk of production to the Claudio-Neronian period rather than the late first to mid/late-second century. This material has been privileged for retention in excavation archives but can now be seen as a proxy for the manufacture of a much wider range of ceramic building material, typically discarded on site, which, in the case of products from Little London and pre-Flavian Minety (Wilts.) travelled distances of up to $100 \mathrm{~km}$. Re-dating implies more extensive public and private building in town and country south and east of the Fosse Way before the Flavian period than has previously been envisaged. While private building included the construction of bath houses, heated rooms and the provision of roofing materials, public building, we suggest, provided 'tabernas et praetoria' along the principal roads of the province. In the private sphere such building provides a possible context for Dio Cassius' mention of the recall and confiscation of large loans made to Britons before the Boudican rebellion. Finally, consideration of fabric needs to be added to the criteria for retaining ceramic building material in excavation archives.

Key words: Boudican, ceramic building material (CBM), Dio Cassius, Fosse Way, Little London, Minety, Nero, pre-Flavian, relief-patterned tile; tabernas et praetoria, tilery

The Boudican destruction horizon identified in Colchester, London and Verulamium is very helpful in giving us insight into the nature of the built environment of those towns and cities before AD 60 and into their slow recovery, especially of Colchester and Verulamium, afterwards. ${ }^{1}$ Pre-Flavian urban development has been identified in other southern towns, too, notably Chichester (and Fishbourne) and Silchester, ${ }^{2}$ and Black sees the presence of 'thin-walled box-tiles' at the port site at Fingringhoe, Essex and the 'proto-palace at Fishbourne, as well as in Colchester and Canterbury as evidence of preBoudican bath building. ${ }^{3}$ This is tantalizing, but is it enough of a context to explain Dio Cassius' comments that the causes of the Boudican revolt included the confiscation of money lent by Claudius to leading Britons which had to be repaid, coupled with the calling-in of a loan equivalent to 40 million sesterces by Seneca. ${ }^{4}$ Who was borrowing and for what? Did it include buildings identified in the three towns which suffered at the hands of Boudica as well in other towns where there is evidence of preFlavian building, but where it is difficult to distinguish between pre- and post-AD 60 contexts? To what extent was Roman-style building, especially of bath houses, only confined to towns before AD 60? Of the several hundred legionaries and auxiliaries retiring each year with their savings and retirement gratuities, how many chose to settle in the province on retirement? How many in the towns, how many in the countryside? How did private projects relate to public building works? The purpose of this paper is to review the question of how far Roman-style building, particularly in masonry, had taken off across Britain outside of a military context, whether before AD 60 or before the Civil War of AD 68-9 and the start of the Flavian dynasty.

In regard to public building works we should pause to consider how the road network was being developed and how precursors of the cursus publicus were supported before Boudica or during the 
Claudio-Neronian period as a whole. If we have a terminus post quem of AD 47/8 for the construction of the road leading west out of London ${ }^{5}$ that subsequently divides to become the road to the north-west (Watling Street) and the road to Silchester and thence to south Wales and the south-west, it is likely that work on the other strategic roads leading in and out of London was equally well advanced to be capable of delivering supplies to the frontier garrisons. By the mid/late 50 s these were controlled by the legions based at Exeter, Usk, Wroxeter and Lincoln. Such a network could also support the movement of manpower between garrisons, including in and out of the province. As a working hypothesis we might envisage the building of road stations, mansiones and mutationes, as an integral part of the support for those using the road network. An inscription dated AD 61/2 from near Philippopolis in Thrace, ${ }^{6} a$ province from AD 46 and, like Britain, lacking roads and much urban infrastructure, records Nero's instruction to his procuratorial governor to build tabernas et praetoria along the military roads. Black interprets the praetorium as, in effect, a mansio, the tabernae as 'shops' and/or 'inns' sitting alongside the mansio in the same location. ${ }^{7}$ Returning to Britain, such projects might not all have been completed by $A D 60$ or by $A D 68 / 9$, but it is hard not to imagine that several were, with others under construction, distributed along the major lines of communication. Equally, it is not difficult to suppose that much of the evidence for these hypothesized early projects has been destroyed by subsequent re-building. For example, Black makes a powerful case for Hadrian initiating a major reform of the cursus publicus associated with a programme of building of mansiones across Britain. ${ }^{8}$

Dating new buildings outside of a military context in pre-Flavian Britain is difficult and, as Black has shown with his examples of potential pre-Boudican bath buildings, considerable reliance has to be placed on proxy evidence. While destruction horizons which can be attributed with confidence to the Boudican revolt can be helpful, as in the cases of Colchester, London and Verulamium, in other urban situations the dating of the earliest buildings whose construction trenches typically cut virgin soil is difficult. Even if they happen to cut earlier ditches or rubbish pits, the character of the associated finds, which will be dominated by coarse pottery, is such as to give a pre-Flavian terminus post quem, inevitably pushing the likely date of build into the later first century. Only more closely dateable samian or a coin, unfortunately more often than not likely to be a Claudian copy with a broad date range, will allow the possibility of further refinement within the period $c$. AD 43- c. AD 70. In a rural setting where dateable finds other than pottery are scarce, the continuity of late Iron Age pottery forms and fabrics up to the late first century $A D$, gives an even broader potential date range. Historically, all of this has inclined us towards seeing $c$. AD 70/the late first century as the period when Roman-style building took off in town and country in southern Britain. This of course chimes well with Tacitus' often cited remark that Agricola, governor of the province AD 78-84, 'gave private encouragement and official assistance to the building of temples, fora and private mansions'. ${ }^{9}$

Some examples of the difficulties of dating to and within the pre-Flavian period may be helpful. Two case studies, Fishbourne and Angmering, from the Sussex group of early villas illustrate this. ${ }^{10}$ The Period 1C 'proto-palace' at Fishbourne is one of two masonry buildings definitely pre-dating the Flavian palace. ${ }^{11}$ Other than that it was sealed beneath the Flavian palace there is no independent evidence with which to date the second masonry building. Likewise, it is its stratigraphical position beneath the Flavian palace which firmly puts the first masonry building, the 'proto-palace', into the pre-Flavian period. However, a more precise date of between AD 65 and 70 for the latter is proposed on the basis of the proxy evidence of the date of the builder's working yard a little way distant to the north. ${ }^{12}$ This contained waste and finished stone from a variety of sources, including imported marbles, which were 
dated by a few sherds supporting a late Neronian-early Flavian date. Because the deposit was sealed beneath make-up for the Period 2 palace, it is attributed to the first Period 1 masonry building, though it could quite possibly relate to an initial stage of building of the Period 2 palace, for example the West Wing, which was built first. ${ }^{13}$ Even if the material from the builder's yard is to be associated with the first or any other of the three pre-Flavian masonry buildings, including Building 3 from the 1995-99 excavations, ${ }^{14}$ the lack of dating evidence directly associated with either the first or the second masonry building does not preclude an earlier start date for one or both of them which could stretch back to the AD 50s. Turning to the dating of the Angmering bath-house, which is cited as a parallel for the bath house of the 'proto-palace' at Fishbourne, we find that the only stratified material cited by the excavator consists of two sherds of samian, 'one of Claudio-Neronian date and the other the base of an Early Flavian Form 18' (not illustrated) found in the brick earth make-up for the floor of Room B. ${ }^{15}$ The Form 18 is better regarded as pre-or early Flavian, rather than simply early Flavian. Notwithstanding further samian and coarse ware of pre-Flavian or pre-or early Flavian date from the excavation, the excavator assigned an overall date of $c$. AD 70-160 for the occupational history of the site from pottery which was found in levelling material post-dating the abandonment and demolition. ${ }^{16}$ On the basis of the stratified pottery a pre-Flavian start date of the occupation cannot be excluded. Finally, the 'Ditches' villa near Cirencester, (Glos.) provides a more recently excavated example where its first phase is dated to 'around the third quarter of the first century AD'. ${ }^{17}$ Other than a single, poorly dated brooch, which might post-date $c$. AD 70, the pottery evidence gives a terminus post quem of AD 50-70. While there is clearly a context for a wider re-examination of the dating of first century Roman buildings in the countryside, these three examples at least show that the evidence can support pre-Flavian start dates or, in the case of the Fishbourne Period $1 \mathrm{C}$ buildings, the possibility of start dates earlier than Neronianearly Flavian.

Let us now turn to some of the materials which pre-Flavian bath houses and other Roman-style buildings used, or could, potentially, have used in their construction. Two new and interlinked projects are shedding important light on the manufacture and consumption of ceramic building materials (CBM): first, research employing petrography and portable XRF has been carried out to characterize and, where possible, provenance the CBM from both antiquarian and modern excavations which were used in building the Roman town at Silchester; ${ }^{18}$ second, excavation of the tilery, one and a half miles south of the Roman town at Little London, Pamber (Hants.), where Lt. Col. Karslake reported the find of a Nerostamped tile in 1925, has provided important insight into the date and range of its products and their consumption in Silchester and across southern Britain. ${ }^{19}$

Considering first the research on the fabrics of the brick and tile used in Silchester, this identified distinctive types which could be associated not only with likely local sources of clay, such as the Windlesham Beds and the more extensive London Clay Formation, but also with more distant production centres, notably Minety in Wiltshire and Eccles in Kent. All the known examples of Nerostamped tiles could be linked by their distinctive fabric to waste material recovered from the ploughsoil at the presumed kiln site located by Karslake at Little London, Pamber. ${ }^{20}$ Following geophysical survey, ${ }^{21}$ which indicated two potential major hotspots, the excavation of one of these at Little London in 2017 not only confirmed the existence of one large tile kiln, but also the inclusion among the waste material from it of two more Nero-stamped tiles. Among a wide range of types of brick and tile, including those necessary for building bath houses, the excavation produced numerous examples of the distinctive, relief-patterned flue-tiles of die types $38,39,54$ and 68 , all variants of the 'diamond and lattice' design ${ }^{22}$ 
(Fig. 1). Relief-patterned tiles of these die types had previously been recorded from a wide range of sites across Berkshire, Gloucestershire, Hampshire, West Sussex and Wiltshire and examination of the fabrics of those pieces that could be located, has confirmed a Little London origin. ${ }^{23}$ Their distribution extends to the north-west to Wanborough (Wilts.) and Cirencester (Glos.) and south to Chichester (W Sussex) and Winchester (Hants.) with an outlier at Rockbourne Roman villa in the south-west of Hampshire (Fig. 2). There is also a possible example of die 38, which could not be located, recorded from Canterbury (Kent). ${ }^{24}$

Fig. 1 about here

Production of brick and tile at Little London took place alongside that of coarse pottery in a range of forms typical of the Claudio-Neronian period, their wasters associated with three small pottery kilns located in a second trench a few metres to the east of the excavated tile kiln. ${ }^{25}$ Although we cannot establish a certain start (indeed, did production begin before Nero's reign?) or end date, production of both pottery and building materials does not appear to have continued beyond the early Flavian period, when brick and tile in a distinctive 'London Clay Formation' fabric came to dominate the Silchester assemblage. ${ }^{26}$ Also, given that pottery made at Little London makes only a slight impression (< one per cent) as a proportion of the Claudio-Neronian pottery assemblage from nearby Silchester, ${ }^{27}$ production at the site appears to have been brief, arguably confined to the reign of Nero. This is supported by the compact date range of the radiocarbon dates from the excavation. ${ }^{28}$ Given that relief-patterned daub has been found in Boudican destruction deposits in Verulamium, ${ }^{29}$ it should not be a surprise that fluetiles marked in this way can now be dated to the reign of Nero and, potentially, from before AD $60 .^{30}$

Turning to the consumption of ceramic building materials within the nearby Roman town of Silchester in the Claudio-Neronian and early Flavian period, a small collection retained from the excavation of Insula IX (Period 1) on the basis of distinctive typological or decorative features and the presence of animal footprints, rather than on a representative sample of the fabrics, has been shown to have included six fabrics of which three, probably four, are likely to be of local origin, while two are from more remote sources. ${ }^{31}$ One of the latter can be matched with examples excavated at Oaksey Park, Minety, the other probably attributable to a source exploiting clay-with-flints, but not matched to any known kiln. While sixteen per cent by count are attributable to the London Clay Formation, at least half and possibly as much as 68 per cent of the retained sample can be matched with the fabrics represented at Little London. Of the non-local sources, eleven per cent can be attributed to Minety ${ }^{32}$ and five per cent to the source using clay-with-flints. Although the Nero-stamped tiles from Little London give a chronological terminus ante quem for this production, we cannot be certain when that at the other two workshops began and ended, but there is clearly some overlap with Little London. One important conclusion of the study of the Silchester material is that pre- and/or early Flavian building projects needed to draw on non-local sources, one of which - Minety - was at least $90 \mathrm{~km}$ distant from Silchester by road. Although a c. AD 100 date has previously been suggested for the start of production associated with the TPFstamped tile at Minety, ${ }^{33}$ the unpublished report of excavations there by A. J. Scammell in the 1970 s shows examples of associated pottery which are typical of the Claudio-Neronian period, and which compare well with the forms produced at Little London. ${ }^{34}$ Perhaps at Minety, too, coarse pottery was produced alongside ceramic building materials in the pre-Flavian period. There is also a record of three 'diamond and lattice' type, relief-patterned flue-tiles of die 56, i.e. one similar to those found at Little London, from this site. ${ }^{35}$ 
In the same way that the relative proximity of Little London to Silchester suggests the latter was the principal consumer of its products, so the location of Minety, some ten kilometres to the south, suggests Cirencester was its main market. However, just as Little London lies close to the roads linking Silchester with Chichester and Winchester, Minety lies between the Fosse Way linking Cirencester with Bath and Ermine Street connecting Cirencester with Wanborough and Silchester, the two kiln locations suggesting that supplying the nearby towns was only part of their ambition. In addition to a supply which reached as far as Silchester, Minety relief-patterned flue-tiles of 'diamond and lattice' die 56 are attested in Cirencester and Bath, where the Minety fabric has also been identified by Machin in situ in the voussoirs used in the vaulting of the baths, and at Wanborough on the road towards Silchester (Fig. 2). ${ }^{36}$ On architectural and art historical grounds a Neronian-early Flavian date for the initial construction of the baths and temple complex at Bath seems not to be in doubt, and it can now be linked, though not necessarily exclusively, to Minety. ${ }^{37}$

Fig. 2 about here

With contemporaneity of production at Little London and Minety, we can see the basis for envisaging several building projects across central southern Britain which were initiated, if not completed, in the Claudian-Neronian period, if not specifically in Nero's reign. It is likely that the building of bath houses was, as at Silchester, a priority, but in most places the remains of whatever was built at this time await discovery. However, we might venture to predict that, as they have been at Bath (but on a grand scale), the remains of pre-Flavian bath houses and/or buildings with rooms heated with hypocausts will eventually be found in other southern towns such as Cirencester, Chichester, Winchester and Canterbury. We should also note the presence of both Little London (dies 39, 54 and 68) and Minety (die 56) patterned flue-tiles at Wanborough on Ermine Street, ${ }^{38}$ where aerial photography has revealed the remains of an, as yet (and probably later), unexcavated mansio. ${ }^{39}$ At present we can only link Little London and Minety products that were actually built into two pre-Flavian structures, the baths at Bath and at Silchester, both substantial 'infrastructure' projects, but with none of the surviving examples of 'diamond and lattice' patterned flue-tile from those tileries attached to any particular building. To date $>70$ such pieces, the great majority comprising large and freshly broken fragments from a partly excavated late $1^{\text {st }}$ century dump, have so far been recovered from the $>20$ tonnes of CBM recovered from the 2018-20 seasons of the ongoing re-excavation of the public baths at Silchester.

Can we build further inferences from this evidence? As we have seen, the locations of both Little London and Minety suggest a degree of compromise between serving the needs of a project or projects in the towns to which they were closest and those of a wider network which could have included the building of mansiones and mutationes (or praetoria et tabernas), such as at Wanborough, along the nearby strategic roads between the larger settlements. While earlier research has highlighted Neronian building activity in general in towns, it is clear from the distribution of relief-patterned tiles from Little London that this also extended in some form to the countryside to what became villas, as at Littlecote (Wilts.) and Rockbourne (Hants.) ${ }^{40}$ and this is also true of Minety die 56, which has also been found at what later became villas at Lechlade (Glos.) Shakenoak (Oxfordshire) and North Wraxall (Wilts.) (Fig. 2). ${ }^{41}$

The coincidence of the manufacture of brick and tile alongside pottery at both Little London and Minety has certainly confirmed a Neronian date for the operation of these industries, but the very nature of the evidence does not exclude the possibility of a late Claudian commencement - the Nero tiles providing a 
terminus ante quem - nor, in the case of Minety, of later production, as of TPF-stamped tile in the second century. ${ }^{42}$ We should also reflect that without the close dating derived from the Nero tiles made at Little London and the presence of Minety brick in pre- and early Flavian Silchester, we could not make this case for Neronian/early Flavian public and private building projects across central southern Britain. But, is there also the possibility of more widespread pre-Flavian building requiring ceramic building materials across south and south-east Britain?

Since the great majority of excavated brick and tile is found loose, divorced from its original structural context, dating it is notoriously difficult, as, for example, is the case with relief-patterned tile in general. Even when found built into a structure, it is difficult to be certain of a primary rather than a secondary use, though the earlier the date of the structure, the more likely it is to be an example of primary use. As we will see below, the residual nature of CBM assemblages cannot be over-emphasised. While none of the examples of relief-patterned flue-tile in the Little London fabric has been found built into a structure, the explicit Neronian association has provided an unequivocal terminus ante quem for this style of decoration thereby raising the possibility that other relief-patterned tile production, particularly that of the 'diamond and lattice' design as found at Little London and Minety, is pre-Flavian in origin elsewhere in the province. Indeed, could all the workshops producing flue-tile marked with this design be associated with a single owner as part of a co-ordinated project to provide building materials for public and private projects across south and south-east Britain? If building projects were going to draw on more than one source of ceramic building materials, as we have seen in the case of those using Little London and Minety products, consistency in the types produced and their dimensions would have been necessary. Tegulae, for example, would need to have been made to the same design and dimensions if the products of different workshops were to be used on the same roof. ${ }^{43}$ To enable projects such as the building of mansio bathhouses to draw on resources from different workshops implies some overarching private or public authority.

Fig. 3 about here

If we plot the distribution of all the finds of the commonest dies, those of 'lattice and diamond' type ${ }^{44}$ we see it extends across southern Britain as far as Bath in the west with finds in Hampshire, Oxfordshire and Wiltshire, but with the greatest numbers recorded from London and the south-eastern counties of Essex, Hertfordshire, Kent, Surrey and Sussex (Fig. 3). There is a marked fall-off north of the Roman road which runs east-west from Colchester through Verulamium and Alchester to Cirencester, though there is a scatter of examples to the north as far as Nottinghamshire and to the north-west along Watling Street as far as Wall. This distribution is almost identical to that of all relief-patterned die types, but with slightly greater numbers north of the Colchester to Cirencester road. ${ }^{45}$ It includes a mix of urban, rural and roadside settlement sites. However, if we plot all the remaining relief-patterned designs ('chevron', 'billet', etc) ${ }^{46}$ other than 'diamond and lattice', the distribution is comparatively restricted, notably excluding the great majority of find sites from Hampshire, Sussex, south Oxfordshire and Wiltshire, the areas in which Little London, Minety and the products of a kiln suspected to be located between Chichester and Arundel in West Sussex have been found (Fig. 4$)^{47}$. Compared with 'diamond and lattice' the distribution is mainly to rural sites, rather than to a mix of urban, rural and roadside settlement sites. Chronology or the marketing strategies of different tileries may provide possible explanations for the difference (see further below, p. 00). Interestingly, there are no recorded relief-patterned tiles of any type from Norfolk and the territory of the Iceni. 


\section{Fig. 4 about here}

Up to the confirmation of a Claudian-Neronian or Neronian date for the Little London products, it has been suggested that the production of relief-patterned tile did not begin until the Flavian period, $c$. AD 75 , then continuing to $c$. AD $155-75 .{ }^{48}$ Such dates can only be regarded as provisional since they are overwhelmingly based on finds divorced from their primary structural context and therefore residual, as is the case with the great majority of examples listed by Betts et al. in their Corpus. Even most of the examples from the seven sites listed where tiles had been found in a dated context or in situ are probably or certainly residual. ${ }^{49}$ The earliest potential examples (of 'diamond and lattice' dies 19 and 21) are from the bath building at Angmering, West Sussex, which, as we have seen above (p. 00), the excavator conservatively dated to the early Flavian period. Our re-examination suggests that an earlier, Neronian or Neronian-early Flavian date is more likely, an important consideration given that the reliefpatterned tile was found in situ at Angmering. This is supported by the evidence from Fishbourne where relief-patterned tile was found in the occupation and destruction levels of the Period 1C 'proto-palace'. ${ }^{50}$ Although the ongoing re-excavation of the public baths at Silchester has so far produced a quantity of Little London relief-patterned flue-tiles, their presumed original context in the Neronian baths was destroyed by the latter's demolition and its replacement with a larger bath house in the late first/early second century. This used a different source of brick, where comb-marked flue-tile overwhelmingly dominates ( 77 per cent by weight, 85 per cent by count) the total flue-tile assemblage of over 8600 pieces (2.17 tonnes) from the site. None of the flue-tile of any period has been found built in its original position. After demolition the Neronian relief-patterned tile was presumably either recycled into the later re-build and its subsequent modifications into the fourth century or was made available for re-use elsewhere in the town to be used as hard core or incorporated in new build. Such a process of re-cycling through the generations may well account for the presence of relief-patterned flue-tile in buildings thought to have been constructed in the second, third, or even the fourth century.

The Little London assemblage makes it clear that the manufacture of relief-patterned flue-tiles did not take place in isolation, but was only one part of the production which embraced a 'complete' repertoire, including bricks, roofing tile, floor tile, flue-tile, including 'thin' scored tile as attested in pre-Boudican Colchester, ${ }^{51}$ voussoir, ${ }^{52}$ and other specialist products required for building a bath house of the period. Waste material was dominated by roofing material and bricks, with hypocaust tile, both plain and keyed, only accounting for 3.7 per cent by count of the assemblage. We should not therefore assume that it was only relief-patterned flue-tiles, themselves representing less than half of the keyed material (but typically all that survives of this production in museum archives) which were transported long distance, nor that such tiles were the products of specialised workshops. Similar conclusions regarding the production of such tile alongside other types and the potential for tileries to have supplied quite large areas were reached by Andrew Middleton et al. in their study of relief-patterned flue-tiles, employing petrography and neutron activation analysis. ${ }^{53}$ We should also note the widespread distribution of Betts et al.'s Fabric Group 1 (= Black's 'London-Sussex' tile group) which extends from Sussex to London and beyond. ${ }^{54}$ This grouping is based on inspection using a hand lens or a low-powered binocular microscope, but it is consistent with the extensive distribution demonstrated for the Little London products. Echoing the distribution of Little London and Minety fabrics, the influence of the road (Stane Street) in the distribution of the London-Sussex group is clear. Similar influences can be seen with other early, but not yet located tileries which supplied London, for example the proposed Eccles fabric group, with a distribution into London across north Kent along Watling Street and out of London to Colchester, 
and the MOLA fabric 3069 found along Watling Street between London and Verulamium. ${ }^{55}$ We should also note the proximity to Stane Street of the known production site of relief-patterned flue-tile at Ashtead Common, Surrey. ${ }^{56}$

The association of relief-patterned flue-tile with Claudian-Neronian or Nero-dated production at Little London has encouraged us to consider first the 'diamond and lattice' group and then the slightly larger entity of all relief-patterned tile. At Little London the life of the tilery may not have extended much, if at all beyond Nero's reign, a short phase of production which is brought out by the comparative rarity of both its pottery and, indeed, its relief-patterned tile at Silchester. The brick and tile so far identified as having been used in the late first/early second century bath-house and dominant in the Flavian forum basilica at Silchester came from a different local (London Clay Formation) source, which has also been identified in small quantities from earlier, pre- and early Flavian contexts from the forum basilica and Insula IX. ${ }^{57}$

The situation at Little London and Silchester raises the question how long production continued at other tileries making relief-patterned brick and tile. In this regard we note that the overall distribution is largely localized to central southern and south-eastern Britain, with all but two find sites (Kenchester, Wall) south and east of the Fosse Way. By far the largest number of finds comes from London where the Corpus lists examples from 103 sites, the majority located within the walled area, with c. 80 per cent producing no more than five such tiles. ${ }^{58}$ Only six sites are listed with more than 20 examples from within the walled area, with the Winchester Palace site in Southwark, south of the river, producing by far the greatest number (178). An absence of finds is noted from the site of the Cripplegate fort dating from c. AD 120. Outside of London only two major towns, Canterbury and Verulamium, are listed with as many as twenty dies, with Chichester, Cirencester, Colchester, Silchester and Winchester represented by between four and eleven die-types. ${ }^{59}$ While the majority (76 per cent) of the 165 find sites (other than London) are rural with only one or two dies listed, there are a few, mainly bath houses and villa sites, with numbers comparable with those from the major towns, e.g. Lullingstone, Kent (10), Fishbourne, W. Sussex (9), Chatley Farm, Cobham, Surrey (9). The same is true of sites with certain or probable praetoria or mansiones, such as Chelmsford, Essex (8) and Lower Wanborough, Wiltshire (8). ${ }^{60}$

Relief-patterned flue-tile has so far not been found in Dorchester (Dorset) (presumed civitas capital from c. AD 80), Exeter (presumed civitas capital from c. AD 80), Gloucester (colonia from AD 96-8) and Wroxeter (presumed civitas capital from the AD 90s), all of which have seen substantial excavations between Lowther's 1948 publication ${ }^{61}$ and the Corpus published in 1997. At Lincoln (colonia late in Domitian's reign (AD 84-96)), also a city which has seen extensive modern excavations, only two pieces are recorded, both from post-Roman contexts (dies 27 and 102), ${ }^{62}$ while at Leicester, the next most northerly town, there is a more substantial assemblage from modern excavations. Lowther published a total of 11 unstratified pieces from the Antonine Jewry Wall (Baths) site (dies 7, 9, 13, 30 and 67) '63 '(in place of the more usual (our italics) 'combed' type)', ${ }^{64}$ while further examples of dies 30 and 67 were found elsewhere in the town including 14 small fragments of die 30 from Little Lane. A stratified example of die 67 was from a late second/early third century context. ${ }^{65}$ The range of dies and the numbers of examples compare favourably with some of the southern towns (other than London) listed above.

Nevertheless, the overall quantities are small, a characteristic that is also found with consumption sites in the south. For example, if we take finds from bath houses, a sure destination for flue-tile, we find 
that, at the Huggin Hill Baths in London, despite references to quantities of broken flue-tile (and other CBM) from the destruction phase, of the three published pieces of CBM from the 1960s excavation, two are of relief-patterned flue-tile (dies 42 and 85). ${ }^{66}$ The 1989 excavations brought the total number of pieces to 43 , still with none found in situ, and a further two dies (5A and 27). ${ }^{67}$ Similarly, at the Cheapside Baths, the only CBM published by Peter Marsden consists of just three fragments of reliefpatterned flue-tile (dies 18, 44 and 63). ${ }^{68}$ Two other fragments (dies 40 and 85) are also recorded from this site. ${ }^{69}$ It is reasonable to conclude that at both sites what was published represents all the pieces of relief-patterned tile recovered from the respective excavations and retained for study. ${ }^{70}$ Both baths underwent significant alteration after their initial construction for which there was either no (Cheapside), ${ }^{71}$ or insufficient evidence (Huggin Hill) of date, ${ }^{72}$ before both were finally abandoned in the second half of the second century (Huggin Hill) ${ }^{73}$ or the late second/early third century (Cheapside). ${ }^{74}$ Although precise numbers have not been published, the excavation of the public baths in Tower Street, Chichester also only produced a small number of pieces ( $>9)$ in four dies $\left(4,48,55\right.$ and 81), ${ }^{75}$ including pieces which can now be attributed to the Little London kiln. ${ }^{76}$ Two pieces of Little London die 81 are from a context, probably a construction trench and therefore pre-dating the baths, where the latest pottery is of Flavian date, providing a terminus post quem for their initial construction. ${ }^{77}$

We can see repeatedly that the lack of even a basic quantification of CBM assemblages from published excavations is a major impediment to understanding the significance of what is reported. One of the larger collections of relief-patterned flue-tile from a single site outside of London is from the mansio and adjacent sites in Chelmsford. Although all the 114 fragments evidencing the use of seven dies (as well as a further 12 pieces from adjacent sites), mostly small and quite abraded, ${ }^{78}$ are carefully tabulated, it is clear from the report on the tile assemblage as a whole that, given the lack of numbers for any other category of CBM, only a small proportion of the original excavated material, but probably including all the relief-patterned flue-tile, was retained for archiving and publication. ${ }^{79}$ We cannot, therefore, assess the significance of that material relative to the rest of the CBM assemblage, including to other types of flue-tile. However, it is important to point out that of the six fragments from stratified contexts dating to the first half of the second century, all are residual in secondary contexts; the earliest from a beamslot of the timber phase of the mansio and dated c. AD 120/5. ${ }^{80}$ The timber phase of the mansio thus gives us a terminus ante quem of $c$. AD 120 for the use of relief-patterned flue-tile in Chelmsford.

One site where there was systematic quantification of the CBM is the tilery at Great Cansiron Farm, Hartfield, East Sussex dated by the associated pottery to the late first/early second century with an archaeomagnetic date for the last firing of AD 100-130. ${ }^{81}$ Here a 'mere' $6.52 \mathrm{~kg}$ of relief-patterned fluetile was recovered, representing 3.9 per cent of the $165.75 \mathrm{~kg}$ of three types of box-flue tile recorded, of which the combed material was far the most dominant type (93 per cent). ${ }^{82}$ This can be compared with the finds at Little London where, out of a sample of over $90 \mathrm{~kg} / 655$ pieces of keyed (combed, relief patterned and scored) and plain flue-tile and parietalis, relief-patterned flue-tile accounts for 20 per cent of the assemblage by weight and count, combed tile only 2 per cent. ${ }^{83}$ The dominance of combing recalls the situation at Flavian Silchester (above, p. 00) but the representation of relief-patterned tile by any measure at Great Cansiron Farm is so slight that it is doubtful whether it was a product of the kiln as it operated in the late first/early second century. Rather, it may be regarded as residual waste from an earlier phase of activity, or from an earlier and, as yet, undiscovered kiln, or debris from the demolition of an earlier structure. The situation is similar to that at Harrold, Bedfordshire where late second century production of relief-decorated tile has been claimed. The evidence is based on only five 
abraded, unstratified fragments, four of which come from the same tile. ${ }^{84}$ These pieces are clearly residual, as their number and condition indicate.

To conclude: the Neronian terminus ante quem at Little London, supported by the evidence from Angmering and Fishbourne, offers an earlier starting date for the production of relief-patterned associated with 'thin' scored flue-tile and parietalis. Of the few types of CBM which appear to have been consistently selected from site collections for deposition in museum archives, especially since Lowther's 1948 publication, the relief-patterned material is an almost unique resource for providing insight into early Roman building activity in southern Britain. ${ }^{85}$ Despite the incidence of finds in London and across southern Britain, the absolute quantities of relief-patterned tile remain small and the combination of this and the earlier start date indicated by Little London lead us to question whether this tradition of keying flue-tile and parietalis continued until the mid-second century AD as has previously been proposed. Not only do the overall small number of finds argue against a long period of production, but the absence from towns in the south-west and west midlands adjacent to the heartland of the distribution and where major building is either to be expected or can be demonstrated, as, for example, with the forum basilica at Exeter, ${ }^{86}$ from the mid-Flavian period, also suggests an earlier termination. This is supported at Silchester where comb-patterned material dominates the flue-tile assemblage and, though mostly unstratified, can reasonably be associated with the rebuilding of the public baths in the late first/early second century and its subsequent modifications. In London Betts et al. note the absence of relief-patterned tile from the site of the Cripplegate fort whose construction is dated to the Hadrianic period. ${ }^{87}$ We suggest that this negative evidence outweighs that for continuity to the mid-late second century where occurrences can be regarded as residual or, if in situ, evidence of re-cycling. Fishbourne once again provides a good example: as we have seen above, relief-patterned tile, which includes Little London material, is first present in the Period $1 \mathrm{C}$ baths, but it is absent from the Third Period North Wing Baths, dating from the beginning of the second century. However, some reappears re-cycled later, presumably via re-use in the adjacent Period 2 Baths, into the Third Period East Baths. ${ }^{88}$ The lack, in our view, of compelling evidence for the continuity of the tradition beyond the late 60 s or early 70 s implies an abrupt cessation of consumption (and production) rather than a slow decline. ${ }^{89}$ Since we now realise that these tiles are the only survivors of a broad-based production and distribution of CBM, the implication is that the break in production in the manufacture of relief-patterned tile equates with that of all the other forms of CBM which were made at the relevant tileries. There are several possibilities to explain a widespread disruption in production: these include the withdrawal of loans prior to the Boudican rebellion as claimed by Dio, and discussed above, and the consequent financial insolvency of those funding the tileries, as well as major upheavals, such as the Boudican rebellion or the Civil War of AD 68-9, which themselves could well trigger the withdrawal of credit. Insolvency could of course occur at any time and need not necessarily be linked to the Boudican revolt. Indeed, and paradoxically, all the evidence for this early development, where debt could have been incurred, is in the wider area affected by the Boudican rebellion, not in the territory of the Iceni. Whatever the reason for the tileries which made brick, including the relief-patterned flue-tile, stopping production, it is likely that the interval before tile-making began again was such that the memory of the old forms of marking tile had been lost, giving way to combing, already coming into fashion at Little London. ${ }^{90}$

Earlier we drew attention to the tendency to date the earliest masonry buildings in the countryside from the $A D 70$ s onwards even when the evidence allows the possibility of earlier start dates from the 50s or 60 s, which is consistent with the earlier start date proposed here for relief-patterned tile. ${ }^{91}$ While it is 
hard to interpret the significance of the many sites with single finds of relief-patterned style - so much depends on the date and scale of excavation - we should certainly entertain the possibility that the 40 or so sites with multiple finds (>2) outside of London included either bath houses or buildings with rooms heated by hypocausts. In terms of Roman building styles and the introduction of bathing to Britain, this gives us an indication of a more developed province (in Roman terms) south and east of the Fosse Way than has previously been thought in the pre-Flavian or, more specifically, the pre-Boudican period. Alongside public works to provide urban bath houses and 'praetoria et tabernas', the predecessors of the later mansiones along the road network, there is considerable evidence for investment in private housing in town and country and especially in London. There are notable blank areas in the overall distribution, notably in East Anglia, corresponding with the territory of the Iceni, a client kingdom up to $A D$ 60, and parts of the South West east of the line of the Fosse Way (east Dorset, east Devon, including the legionary fortress at Exeter, and Somerset), still under military control until c. AD 70.92 Alternatively, these absences may be explained by the practice of different traditions in the making of flue-tile, though they are also areas without evidence of first century villas. We noted above that, compared with the 'diamond and lattice' style, other patterns are extremely rare in the southern counties of Hampshire and West and East Sussex, those generally considered to have fallen within the client kingdom of Cogi/Togidubnus. Perhaps the explanation for this is chronological, with the appearance of construction employing predominantly 'diamond and lattice' roller-stamped flue-tile slightly later and, in the south, linked to imperial support for the client kingdom as recognition of its loyalty during the Boudican rebellion (and in sharp contrast with the stark absence of relief-patterned flue-tile in the territory of the Icenian kingdom). Where the Nero-stamped tile, found so far (apart from Little London) only in Silchester, is concerned, the building may relate to those 'civitates' of the client kingdom ceded to that emperor. Perhaps the distribution of the Little London products correlates to some degree with those civitates? ${ }^{93}$

If chronology is indeed the explanation for the differential distributions, one implication is that Romanstyle construction, including of bath houses, was underway in London and the adjacent towns (Colchester, London, Verulamium) and countryside in the 50s, if not from the late $40 \mathrm{~s}$. This leads us to the question, who was paying for, or borrowing to pay for this building in town and country? While members of British tribal elites may have been partly responsible, we might also consider whether veteran settlers could account for this phenomenon. At the beginning of this paper we questioned whether and where veterans with their disposable cash might have chosen to remain in Britain. While the veterans of legio XX might have settled near their colonia at Colchester, given that the next colonial foundations at Gloucester and Lincoln were not laid until the end of the first century, what happened to veterans from the other legions and units who settled in the province? Were they encouraged to acquire virgin land or existing farms from their British owners more widely across the province, but in the demilitarized zone south and east of the Fosse Way which, with a very few exceptions, marks the limit of the distribution of relief-patterned tile?

Another important conclusion of this paper is that it can be securely demonstrated that ceramic building material travelled significant distances to the places where it was used in this early, pre-Flavian period. We are fortunate that relief-patterned tile has been retained in site archives because, in light of Little London, it can be used as a proxy for ceramic building material in general. Identification by petrographic analysis of products from Little London up to $100 \mathrm{~km}$ from the kilns strongly supports earlier research based on die evidence and inspection of fabrics with hand lens or binocular microscope that CBM of all 
types could travel considerable distances, mostly by road, a tribute to the capacity for the roads to take heavy traffic in the pre-Flavian period. By the same token individual building projects were able to draw on more than one source for the brick and tile they required. If we are correct in our interpretation that relief-patterned tile-making was a phenomenon of the 50 s and 60 s, further work on the characterization of fabrics will give valuable insight into the number of tileries operating and therefore of the scale of pre-Flavian civil construction in Britain.

The focus on relief-patterned flue-tile is a reflection of how it has been selected from site collections no doubt influenced by, first, Lowther's study published in 1948 and more recently by Betts et al. (1997) - to be deposited in museum archives by virtue of its appearance and relative scarcity at the expense of the great majority of ceramic building material excavated from any one site which has all too frequently been discarded without record. Historic collections of CBM retained in museum archives tend only to include stamped, decorated or otherwise unusually marked pieces, or tiles with animal footimpressions, rather than representative samples of the range of forms and fabrics from each site. An important lesson for the future is that, in the knowledge that Roman building projects, both public and private, commonly drew on ceramic building material from more than one source and that such sources might be some distance from the point of consumption, we need to record the quantities of the CBM recovered from an excavation, not just by the various types represented, as is more commonly the case now, but by their fabrics as well. Representative samples of the different fabrics should be a required element of the deposited CBM archive of any site. ${ }^{94}$

In making a claim for a focus of early, i.e. pre-Flavian construction projects in town and country across much of Britain south and east of the Fosse Way, this paper provides a context for determining whether similar kinds of development were undertaken subsequently more widely across the province, in the south-west, the midlands, the north and in Wales, which might include the co-ordinated provision of infrastructure to support the cursus publicus and movement more generally along the main arteries of the province. Fabric characterisation will also help us to determine how tilery markets changed over time.

Acknowledgements

We are very grateful to lan Betts, Ernest Black and Peter Warry for their helpful comments on this paper.

Department of Archaeology, University of Reading

m.g.fulford@reading.ac.uk

s.l.machin@reading.ac.uk

Figure captions:

Fig. 1. Examples of relief-patterned tile (dies 38, 39, 54 and 68) from the 2017 excavation at Little London, Pamber, Hants.

Fig. 2. Distribution of relief-patterned tile from Little London, Hampshire and Minety, Wiltshire

Fig. 3. Distribution of finds of relief-patterned tile using dies of 'diamond and lattice' type.

Fig. 4. Distribution of relief-patterned tile using dies other than those of 'diamond and lattice' type. 
${ }^{1}$ For overviews see Crummy, 85-90; Fulford 2008, 8-11; Hingley 2018, 57-67; Niblett 2001, 60-73; Niblett and Thompson 2005, 146-52; Wallace 2014.

${ }^{2}$ Fulford 2008.

${ }^{3}$ Black 1996, 60-2.

${ }^{4}$ Dio Cassius, Epitome Ixii, 2.

${ }^{5}$ Hill and Rowsome 2011, 22-6.

${ }^{6}$ CIL III.2.6123.

${ }^{7}$ Black 1995, 10.

${ }^{8}$ Black 1995, 8, 32-47.

${ }^{9}$ Agricola xxi; translation by Mattingly (1948), 72.

${ }^{10}$ Allen 2016, 90-7, Fig. 4.19; Rudling 1998; and, for a recent survey of early 'palaces' and 'villas' in Roman Sussex, see Russell 2006.

${ }^{11}$ Cunliffe 1971a, 61-72.

${ }^{12}$ Cunliffe 1971a, 58-60.

${ }^{13}$ Cunliffe 1971a, 80.

${ }^{14}$ Manley and Rudkin 2005, 16-29.

${ }^{15}$ Scott 1938, 12.

${ }^{16}$ Scott 1938, 13; Lancaster 2012, 424.

${ }^{17}$ Trow et al., 2009, 25-6, 137-8.

${ }^{18}$ Machin, S. 2018.

${ }^{19}$ Fulford, et al. 2017; Fulford et al., forthcoming.

${ }^{20}$ Machin 2018, 98.

${ }^{21}$ Linford, et al. 2016.

${ }^{22}$ The miscellaneous die type 54 was also found at Little London.

${ }^{23}$ Machin 2018, 242-55.

${ }^{24}$ Although, primafacie, this might seem unlikely as Canterbury is a long way from Little London, Silchester has so far produced a dozen or so pieces of CBM made at Eccles in Kent (SILCBM8 in Machin 2018, 121-3)

${ }^{25}$ Fulford, et al., 2017

${ }^{26}$ Machin 2018, 179-225, especially, 222-5.

${ }^{27}$ Timby 2020, 372-3.

${ }^{28}$ Derek Hamilton, pers. comm.

${ }^{29}$ Frere 1972, 160-2, pl. LIV.

${ }^{30} \mathrm{Cf}$. Lancaster 2012, 435-6.

31 Machin 2020.

32 Timothy Darvill independently attributed the fabric of the undated, but probable second century, LHS-stamped tile from Silchester to his Minety fabric $(1979,328)$.

${ }_{33} \mathrm{Ibid}$., 312-13, 325-7.

${ }^{34}$ Scammell, nd.

${ }^{35}$ Betts et al. 1997, 118-20.

${ }^{36}$ Idem.

${ }^{37}$ Blagg 1979; Cousins 2016.

${ }^{38}$ Betts et al. 1997, 109, 118-20, 126.

39 Phillips and Walters 1977.

${ }^{40}$ Machin 2018; Machin forthcoming.

${ }^{41}$ Betts et al., 1997, 118-20.

42 Darvill 1979, 312-3.

${ }^{43}$ The Minety assemblage recovered by Scammell (note 33) includes a tegula with a cutaway of Warry (2006) Type $\mathrm{C5}$, exactly the same as used for all the tegulae found at Little London.

${ }^{44}$ Betts et al., 1997, 56-60; the find spots are taken from the Corpus catalogue, ibid., 65-161. Ian Betts informs us of a small number of further finds of both 'diamond and lattice' and other die types which have been reported to 
him since the publication of the Corpus. With the exception of a single find from York, the remaining finds are from south-eastern counties of Cambridgeshire (1), Essex (1), Hertfordshire (1) and Kent (>10).

${ }^{45}$ The find spots are taken from the Corpus catalogue, ibid., 65-161.

${ }^{46}$ Betts et al., 1997, 53-5, 60-2.

${ }^{47}$ The London-Sussex tile group, Betts et al., 1997, 19-20; Betts 2017, 372-3, Fig.17.5; the find spots are taken from the Corpus catalogue, Betts et al., 65-161.

${ }^{48}$ Black 1985.

${ }^{49}$ Betts et al., 1997, 40.

${ }^{50}$ Cunliffe 1971 b, 43, Nos $3 \& 4$. We should also note that an example of die 81 in the Little London fabric has now been identified by Machin at Fishbourne (Ibid., pl. xii, unnumbered bottom right).

${ }^{51}$ Machin, forthcoming. Of the 345 fragments of flue-tile with keying, 190 ( 55.1 per cent) were by scoring, 136

(39.4 per cent) were by roller-stamping and 16 (4.6 per cent) were by combing. A further three parietalis were also keyed by roller-stamping. The tile knife-scored with lattice design is 'thin', averaging $19 \mathrm{~mm}$ in thickness. The thicknesses of the relief-decorated tile range from $14.6 \mathrm{~mm}$ (die 54 ) to $21.5 \mathrm{~mm}$ (die 39). Black $(1996,60)$ reports thin, scored tile in pre-Boudican Colchester.

${ }^{52}$ Both solid and 'armchair' types.

53 Middleton et al., 1992, 53-5.

${ }^{54}$ Betts 2017, Fig. 17.5.

${ }^{55}$ Betts 2017, Figs 17.3, 17.8.

${ }^{56}$ Lowther 1927; 1930; Bird 2014

${ }^{57}$ Machin 2018, 222-5.

${ }^{58}$ Betts et al., 1997, 35-9.

${ }^{59}$ Betts et al., 1997, 26-8.

${ }^{60}$ Idem.

${ }^{61}$ Lowther 1948a.

62 Betts et al.,1997, 27.

${ }^{63}$ Lowther 1948b.

${ }^{64}$ Lowther 1948b, 275.

${ }^{65}$ Betts et al., 1997, 102, 126.

${ }^{66}$ Marsden 1976, 58-9.

${ }^{67}$ Betts et al., 1997, 36.

${ }^{68}$ Marsden 1976, 65-6.

${ }^{69}$ Betts et al., 1997, 35.

${ }^{70}$ Though this is perhaps less the case at Cheapside, excavated under rescue conditions (Marsden 1976, 30), where only a very small percentage of the building material present was collected.

${ }^{71}$ Marsden 1976, 34.

72 Marsden 1976, 19-20.

73 Marsden 1976, 22-3.

74 Marsden 1976, 38.

${ }^{75}$ Betts et al., 1997, 69, 115, 118, 133.

${ }^{76}$ Machin, forthcoming.

77 Down 1978, 142-4.

${ }^{78}$ See the very few even meriting illustration (Wickenden and Drury 1988, Fig. 59).

79 lbid., , 79-85.

${ }^{80}$ Drury 1988, 27.

${ }^{81}$ Rudling 1986.

${ }^{82}$ Foster 1986.

${ }^{83}$ Machin, forthcoming; cf note 51 , which just considers the keyed material.

${ }^{84}$ Brown 1994; Betts et al., 1997, 123-5.

${ }^{85}$ Relief-patterned tile is not the only type of CBM to be affected by the Neronian dating of Little London. The tilery produced tegulae with cutaways of Warry's Type C5 which he has dated c. AD 160-260 (2006, 58-64). Now it is clear that production of this type began about a century earlier in the pre-Flavian period.

${ }^{86}$ Bidwell 1979, 86-7. 
${ }^{87}$ Betts et al., 1997, 36.

${ }^{88}$ Cunliffe 1971a, 154-7; 172-80; Cunliffe 1971b, 45-9.

${ }^{89}$ With as yet no evidence of pre-Flavian occupation in York, the find reported from there (note 44), when confirmed, would extend some production into the 70s. It is interesting to note that relief-patterned tile has been reported from sites east of the Rhine in southern Germany (Baatz 1988; Betts et al. 1997, 46). Although

production has been dated to the second half of the second century, all the sites with such tile have been found on sites which were founded in the Flavian period when, given the issue of residuality, production might have started then - perhaps by tilemakers leaving Britain to seek new contracts.

${ }^{90}$ See note 51.

${ }^{91} \mathrm{Cf}$ the overall distribution of first century villas, Allen and Smith 2016, 34-6, Figs 2.20-1.

92 Manning 2002, 32-7, Fig. 2.2.

${ }_{93}$ Peter Warry suggested that imperial control might explain why Little London products have not so far been found in London (2012, 52), but, if Little London was slightly later, demand in London might already have been met by more local producers. It can surely only be a matter of time before Nero-stamped tile is found among Little London CBM elsewhere than at Silchester. Of the examples recorded so far, all but one are on tegulae.

${ }^{94}$ Baxter et al., 2018. 